
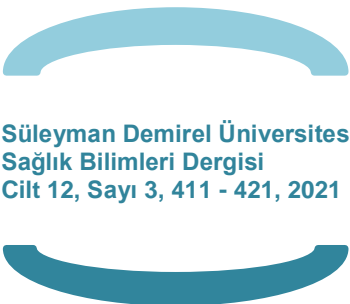

\title{
Çocuk Cinsel İstismarını Önlemede Okul Temelli Cinsel İstismarı Önleme Programlarının Önemi
}

\section{The Importance of School-Based Sexual Abuse Prevention Programs in Preventing Child Sexual Abuse}

\author{
Duygu KEMER ${ }^{1 * \mathbb{D}}$, Ayşegül işLER DALGIÇ ${ }^{2}$ (D)
}

\begin{abstract}
${ }^{1}$ Harran Üniversitesi, Sağlık Bilimleri Fakültesi, Çocuk Sağlığı ve Hastalıkları Hemşireliği Anabilim Dalı, Şanlıurfa, Türkiye
${ }^{2}$ Akdeniz Üniversitesi, Hemşirelik Fakültesi, Çocuk Sağlığı ve Hastalıkları Hemşireliği Anabilim Dalı, Antalya, Türkiye
\end{abstract}

\begin{abstract}
Ö ZE T
Çocukların sağlığını tüm boyutlarıyla olumsuz yönde etkileyen cinsel istismar, acil önleme stratejilerinin uygulanmasını gerektiren global bir sorundur. Bu derlemenin amacı çocuk cinsel istismarını önlemede okul öncesi dönemden itibaren uygulanmaya başlanması gereken okul temelli çocuk cinsel istismarı önleme programlarının önemini ortaya koymaktır. Okul temelli cinsel istismarı önleme programları, çocuklara cinsel istismar hakkında bilgi verme, potansiyel istismar olaylarından kaçınma ve kişisel güvenlik becerileri kazandırmaya odaklanır. Literatürde cinsel istismarın önlenmesinde okul temelli cinsel istismarı önleme programlarının çocukların cinsel istismar ile ilgili kavramları ve kendini koruma becerileri konusundaki bilgilerini artırmadaki etkinliği kanıtlanmıştır. Ülkemizde uygulanmamasına karşın gelişmiş ülkelerde erken çocukluk döneminden başlayarak okul temelli cinsel istismarı önleme programları uygulanmakta ve çocukların cinsel istismara karşı uyanık, bilinçli ve donanımlı olmaları hedeflenmektedir. Bu programlar çoğunlukla Amerika, Kanada, İngiltere, İrlanda ve Avustralya'da deneysel çalışmalar ile değerlendirilmektedir. Son zamanlarda okul temelli programlar; Kore, Tayvan ve Çin'de değerlendirilmiştir. Okul temelli cinsel istismarı önleme programlarının ortak temaları; bedeni tanıma, uygun ve uygun olmayan dokunmayı tanıma, iyi ve kötü sırlar arasındaki farkı öğrenme, sır saklamama, riskli durumlarda "hayır" diyebilme, ortamdan ayrılabilme ve olayı güven duyduğu birine anlatmadır. Çocuk istismarının önlenmesinde okul temelli cinsel istismarı önleme programlarının etkinliği kanıtlanmasına rağmen Ülkemizde kullanılmadığı, bu alanda yapılan araştırmaların yetersiz olduğu ve hemşirelerin konuya ilişkin yapacakları araştırmaların sayısının ve niteliğinin artmasının önemine dikkat çekilmiştir.
\end{abstract}

Anahtar Kelimeler: Cinsel istismarı önleme, okul temelli cinsel istismarı önleme eğitim programı, okul öncesi çocuk, okul öncesi eğitim, hemşire

Alınış / Received: 23.02.2021 Kabul / Accepted: 04.08.2021 Online Yayınlanma / Published Online: 20.12.2021 


\section{$\cos 2020$}

\section{A B S T R A C T}

Sexual abuse, which negatively affects children's health in all dimensions, is a global problem that requires urgent prevention strategies. The purpose of this review is to reveal the importance of school-based child sexual abuse prevention programs, which should be implemented as of preschool age in preventing child sexual abuse. School-based sexual abuse prevention programs focus on providing children with information about sexual abuse, avoiding potential abuse and providing personal safety skills. In the literature, the effectiveness of school-based sexual abuse prevention programs in preventing sexual abuse has been proven in increasing children's knowledge about the concepts of sexual abuse and self-protection skills. Although not implemented in our country, school-based sexual abuse prevention programs are implemented in developed countries starting from early childhood, and children are aimed to be alert, conscious and equipped against sexual abuse. These programs are mostly evaluated with experimental studies in the USA, Canada, England, Ireland and Australia. Recently, school-based programs; It has been evaluated in Korea, Taiwan and China. Common themes of school-based sexual abuse prevention programs; Knowing the body, recognizing appropriate and inappropriate touch, learning the difference between good and bad secrets, not keeping secrets, being able to say "no" in risky situations, leaving the environment and telling the event to someone you trust. Although the effectiveness of school-based sexual abuse prevention programs in the prevention of child abuse has been proven, it was pointed out that they are not used in our country, the researches in this field are insufficient, and the importance of increasing the number and quality of research that nurses will do on the subject.

Keywords: Sexual abuse prevention, school-based sexual abuse prevention education program, preschool child, preschool education, nurse

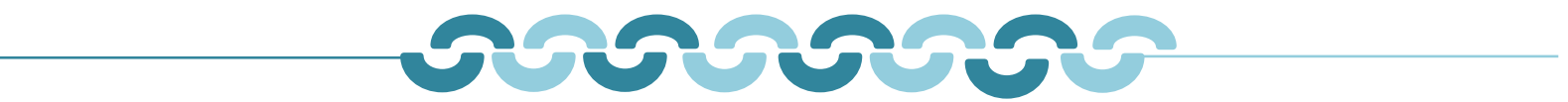

\section{Giriş}

Herhangi bir ırk, bölge, sosyo-ekonomik durum, eğitim ve statü fark etmeksizin tüm dünyada görülen, çocukların sağlığını fiziksel, duygusal, ruhsal tüm boyutları ile olumsuz yönde etkileyen çocuk cinsel istismarı ciddi bir toplumsal sorundur [1]. Dünya Sağlık Örgütü (DSÖ)'nün 2017'de yayımladığı "Çocuklara Yönelik Kötü Muamele" başlıklı raporda, dünya genelinde \%18'i kız, \%8'i erkek olmak üzere çocukların \%26'sının cinsel istismara maruz kaldığı bildirilmiştir [2]. Tüm dünyada olduğu gibi Türkiye'de önemli bir toplumsal sorun olan çocuk istismarına ilişkin Türkiye İstatistik Kurumu (TÜIK) 2016-2017 yılları verilerine göre cinsel istismar vakaların \%13'ünün erkek, \%87'sinin kız çocuk olduğu bildirilmiştir [3].

Cinsel istismarın çocuk üzerinde son derece olumsuz etkileri olabilmektedir. Cinsel istismara uğramış çocukların yaşadığı duygusal ve psikososyal sorunları belirlemeye yönelik yapılan bir çalışmada $(\mathrm{n}=443)$, umutsuzluk (\%46.5), tekrar olacağı korkusu (\%52.8), güvensizlik (\%36.8), uyku sorunları (\%32.7), gelecek hakkında olumsuz düşüncüler (\%32.1) ve kendini suçlama (\%31.1) gibi olumsuz etkiler bildirilmiştir [4]. Araştırmalar cinsel istismara uğramış çocukların, çocukluk döneminde ve yaşamları boyunca; anksiyete ve depresyon, post-travmatik stres bozukluğu, alışılmadık saldırgan davranışlar, kendi kendine zarar verme, suçluluk duygusu, okul başarısında düşme, okuldan ayrıma, uyku ve yeme bozuklukları, parmak emme, tırnak yeme, enüresis, enkopresis gibi davranış bozuklukları gibi ciddi olumsuz sonuçlara maruz kalma intimallerinin daha yüksek olduğunu göstermektedir [4-6].

Çocuğa yönelik cinsel istismar sorununun nasıl ele alınacağına ilişkin en temel hedef istismar gerçekleşmeden önce istismarın önlenmesidir [7]. Cinsel istismarı önleme stratejilerinin okul temelli eğitim programları ile uygulanması gerektiği vurgulanmaktadır. Bu eğitim programlarının uygulanmaya başlanması gereken yaş 3-6 yaş yani okul öncesi dönemdir [8,9]. Okul öncesi dönemden başlayarak 
okul temelli eğitim programlarının uygulanması çocuklara yönelik cinsel istismarı önlemede son derece önemlidir. Bu derlemenin amacı okul öncesi dönemden itibaren uygulanmaya başlanması gereken okul temelli çocuk cinsel istismarı önleme programlarının önemini ortaya koymaktır.

\section{Neden Okul Öncesi Dönem?}

Okul öncesi yaş dönemi çocukların bedensel, sosyal-duygusal, bilişsel ve dil gelişimi büyük ölçüde tamamlandığı ve öğrenme hızının çok yüksek olduğu bir dönemdir. Freud'a göre bu dönemdeki çocuk cinsel kimliğin ve sağııkı kişilik gelişiminin temellerinin atılığı fallik dönemdedir. Cinsiyet farklılıklarının öğrenildiği ve bedeni keşfetmeye meraklı olunduğu bir dönemdir. Vücudunu başkaları ile karşılaştırır. Farklıııkları araştırmak için arkadaşları ile doktorculuk gibi oyunlar oynar [10,11]. Okul öncesi dönemde alınan eğitim çocuğun hayatını doğrudan etkilemektedir. Bu nedenle çocuğun bedenini tanıma ve beden güvenliği eğitimi için en uygun yaş dönemi okul öncesi dönemdir [1,8,11-13]. Literatürde okul öncesi ve anaokulu öğrencilerinin kendini koruma becerilerini ve istismar kavramlarını öğrenebileceklerini gösteren çok sayıda araştırma vardır [8,9,11,13-15].

\section{Neden Okul Temelli Eğitim Programları?}

Çocuk cinsel istismarının önlenmesi birincil hedef, okul temelli programların oluşturulması ve okullarda bu programların müfredat olarak kabul görmesi ve yaygın hale getirilmesidir. Çocuklara kolay ulaşım sağlandığı ve çocukların yaşamlarının büyük bir kısmı okullarda geçtiği için çocuk cinsel istismarı önleme stratejilerinin okul temelli programlar ile uygulanması gerektiği vurgulanmaktadır $[8,16,17]$. Okul temelli cinsel istismarı önleme programları, çocukların cinsel istismarı önleme konusundaki bilgilerini artırmada, beden güvenliği kurallarını ve becerilerini öğretmede son derece önemlidir. Bu eğitimde çocuklara "bedenim bana ait bilinci"nin kazandırılması temel hedef olmalıdır. Bu programların temel amacı; çocukların potansiyel istismar içeren durumları veya potansiyel istismarcıları tanımasına yardımcı olmaktır. Potansiyel istismar içeren durumlarda çocuklara; "Hayır" demeyi, o kişi ve ortamdan uzaklaşmayı öğretmek, önceden olan veya devam eden istismarı güvenilir bir yetişkine bildirmeye teşvik etmek ve gizli veya uygun olmayan dokunmanın asla kendisinin sorumluluğu olmadığını öğretmek son derece önemlidir $[8,9,11,14,18,19]$.

\section{Okul Temelli Cinsel İstismarı Önleme Programları ile ilgili Yapılan Çalışmalar}

Okul temelli cinsel istismarını önleme eğitim programları ilk olarak 1970'ler [20] özellikle ilkokul çağındaki çocuklarda uygulanmıştır [21]. Okul temelli programlar, Amerika ve Kanada'da 1980'lerin başında çocuklara yönelik cinsel istismarı önlemek ve geniş çapta yaygınlaştırmak için oluşturulmuştur [22]. Daha sonra ebeveynleri dahil etmeye yoğun bir vurgu yapan okul öncesi eğitim programları geliştirilmiş [23] ve nispeten yaygınlaşmıştır [14,24]. Çocuk cinsel istismarını önlemeye yönelik okul temelli programlar çoğunlukla Amerika, Kanada, İngiltere, İrlanda ve Avustralya'da deneysel çalışmalar ile değerlendirilmektedir. Son zamanlarda okul temelli programlar; Güney Afrika [25], Malezya [26], Kore [27], Çin, Tayvan [15,28] ve Ekvador'da [29] uygulanmaktadır. Okul öncesi dönemde çocuk cinsel istismarını önlemeye yönelik farklı ülkelerde yapılan okul temelli eğitim programlarının etkinliğini değerlendiren araştırmalar Tablo 1'de sunulmuştur. 


\begin{tabular}{|c|c|c|c|c|c|}
\hline $\begin{array}{l}\text { Yazarlar/ } \\
\text { Ülke }\end{array}$ & Hedef grup & $\begin{array}{l}\text { Programın } \\
\text { adı }\end{array}$ & Süresi & $\begin{array}{l}\text { Yöntem ve } \\
\text { materyal }\end{array}$ & Bulgular ve Sonuç \\
\hline $\begin{array}{l}\text { Boyle ve } \\
\text { Lutzker, } \\
2005 / \\
\text { Gürcistan }\end{array}$ & $\begin{array}{l}\text { 5-6 yaş } \\
\text { arası üç } \\
\text { çocuk, } \\
\text { kontrol } \\
\text { grubu yok }\end{array}$ & - & 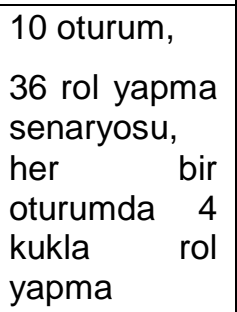 & $\begin{array}{l}\text { Kukla ile rol } \\
\text { yapma } \\
\text { senaryoları }\end{array}$ & $\begin{array}{l}\text { Üç çocuğun kukla ile rol-play senaryoları eğitim sonrasında uygun/uygun olmayan } \\
\text { dokunuşları ayırt etmede ölçekten aldıkları puanlarda artış göstermiş, bu artışlar } 3 \text { ve } 6 \\
\text { haftalık izlemlerde de devam etmiştir. }\end{array}$ \\
\hline $\begin{array}{l}\text { Kenny, } \\
\text { 2009/USA }\end{array}$ & $\begin{array}{lr}114 & \\
\text { ebeveyn ve } \\
3-5 \quad \text { yaş } \\
\text { arası } & 122 \\
\text { çocuk } & \end{array}$ & $\begin{array}{lr}\text { Parents } & \text { as } \\
\text { Teachers } & \text { of } \\
\text { Safety } & \\
\text { (PaTS) }\end{array}$ & $\begin{array}{l}\text { Toplam } 17 \\
\text { aylık dönem: } \\
\text { haftada iki } \\
\text { kez } 1 \text { saat, } \\
\text { sekiz hafta } \\
\text { boyunca }\end{array}$ & - & $\begin{array}{l}\text { PaTS, cinsel istismarı önleme ile ilgili bilgi ve becerileri geliştiren, çevresel ve kişisel } \\
\text { beden güvenliği kuralları hakkında bilgilendiren, okul öncesi çocuklar ve aileleri için } \\
\text { psiko-eğitimsel bir yaklaşım kullanan bir eğitim grubudur. Bu program, ebeveyn ve } \\
\text { çocuk arasındaki iletişimi artırma, çocuk cinsel istismarı ve çevre ile ilgili potansiyel } \\
\text { tehlikeler hakkında çocuk ve aileleri eğitmede ve ebeveynler için çocuklarıyla } \\
\text { konuşurken davranışsal rehberlik hedeflerine ulaşmada başarılı bulunmuştur. Ayrıca } \\
\text { çocukların uygunsuz dokunma bilgisini ve cinsel istismarı bildirme becerilerini } \\
\text { artırmıştır. }\end{array}$ \\
\hline $\begin{array}{l}\text { Kenny ve } \\
\text { Wurtele, } \\
\text { 2010/USA }\end{array}$ & $\begin{array}{lr}3-5 & \text { yaş } \\
\text { arası } 93 \\
\text { çocuk, } \\
\text { kontrol } \\
\text { grubu yok }\end{array}$ & $\begin{array}{l}\text { Body Safety } \\
\text { Training } \\
\text { Program } \\
\text { (BST) }\end{array}$ & $\begin{array}{lr}6 & \text { hafta } \\
\text { boyunca, } & \\
\text { haftada iki } \\
\text { kez } 1 \text { saat } \\
\text { olmak üzere } \\
\text { toplam } & 12 \\
\text { saat }\end{array}$ & $\begin{array}{l}\text { Beden } \\
\text { güvenliği } \\
\text { eğitimi kitabı, } \\
\text { senaryo }\end{array}$ & $\begin{array}{l}\text { Ön testte çocukların "kötü" bireylere kıyasla, "iyi” bireyler tarafından uygun olmayan } \\
\text { dokunma isteklerini tanımakta daha fazla zorluk çektikleri saptanmıştır. Beden } \\
\text { güvenliği eğitim (BGE) programı tamamladıktan sonra çocukların hem "iyi" hem de } \\
\text { "kötü" bireyler tarafından yapılan uygun olmayan dokunma durumlarını tanıma } \\
\text { yeteneklerinin geliştiği belirtilmiştir. } 4 \text { ve } 5 \text { yaşındaki çocukların neredeyse tamamı } \\
\text { (sırasıyla \%94 ve \%96), } 3 \text { yaşındaki çocuklara (\%71) göre uygun olmayan dokunma } \\
\text { isteklerine doğru yanıt vermiştir. }\end{array}$ \\
\hline $\begin{array}{l}\text { Kenny et } \\
\text { al., } 2010 / \\
\text { USA/Latino }\end{array}$ & $\begin{array}{ll}-5 & \text { yaş } \\
\text { arası } & 105 \\
\text { çocuk } & \end{array}$ & $\begin{array}{l}\text { Kids } \\
\text { Learning } \\
\text { about Safety } \\
\text { program }\end{array}$ & $\begin{array}{l}\text { Haftada iki } \\
\text { kez, } 16 \text { saat } \\
\text { psikoeğitim }\end{array}$ & $\begin{array}{l}\text { Modelleme, } \\
\text { didaktik } \\
\text { öğretim ve } \\
\text { bibliyoterapi }\end{array}$ & $\begin{array}{l}\text { Çocukların genel güvenlik kavramları ve kişisel güvenlik kuralları konusundaki } \\
\text { bilgilerinde gelişmeler saptanmıştır. } 3 \text { aylık izlemde bilgilerinin korunduğu ve } \\
\text { programdan memnuniyetlerinin devam ettiği bildirilmiştir. }\end{array}$ \\
\hline
\end{tabular}




\begin{tabular}{|c|c|c|c|c|c|}
\hline $\begin{array}{l}\text { Kenny et } \\
\text { al., } 2012 / \\
\text { USA/Latino }\end{array}$ & $\begin{array}{l}3-5 \text { yaş } \\
\text { arası } \\
78 \text { çocuk } \\
\text { (Deney:33, } \\
\text { Kontrol:45) }\end{array}$ & \begin{tabular}{|l|} 
Kids \\
Learning \\
about Safety \\
program
\end{tabular} & \begin{tabular}{|l|} 
Haftada iki \\
kez, 10 saat \\
psikoeğitim
\end{tabular} & \begin{tabular}{|l|} 
Modelleme, \\
didaktik \\
öğretim ve \\
bibliyoterapi
\end{tabular} & $\begin{array}{l}\text { Girişim grubunda, kişisel güvenlik becerileri ve genel güvenlik kurallarını öğrenmede } \\
\text { anlamlı düzeyde artış görülmüştür. Girişim grubundaki çocukların; uygun olmayan } \\
\text { dokunmayı tanıma yeteneği gelişmiş, bedenin bölgelerini ve doğru genital terminolojiyi } \\
\text { öğrenmiş ve "iyi" insanlar tarafından yapılan dokunma isteklerinin uygunsuzluğunu da } \\
\text { ayırt edebilmiştir. Genital terminoloji dışındaki tüm alanlar için üç aylık izlem testlerinde } \\
\text { de bilgi kazanımları devam etmiştir. }\end{array}$ \\
\hline $\begin{array}{l}\text { Zhang et } \\
\text { al., 2014/ } \\
\text { Çin }\end{array}$ & $\begin{array}{l}\text { 3-5 yaş } 150 \\
\text { çocuk } \\
\text { (Deney:78, } \\
\text { Kontrol:72) }\end{array}$ & $\begin{array}{l}\text { Body Safety } \\
\text { Training } \\
\text { Program }\end{array}$ & \begin{tabular}{|lr} 
Bir & hafta, \\
günde & 1 ders
\end{tabular} & \begin{tabular}{|l|} 
Beden \\
güvenliği \\
eğitimi kitabı, \\
senaryo
\end{tabular} & $\begin{array}{l}\text { Girişim grubundaki çocukların kontrol grubuna göre kendini koruma becerilerinin ve } \\
\text { cinsel istismarı önleme konusundaki bilgilerinin daha fazla olduğu bulunmuştur. } \\
\text { Sonuçta, cinsel istismarı önleme eğitimi uygulanmasının mümkün olduğu belirtilmiştir. }\end{array}$ \\
\hline $\begin{array}{l}\text { Citak } \\
\text { et Tunc } \\
2018 / \text { al., } \\
\text { Türkiye }\end{array}$ & $\begin{array}{lr}3-6 & \text { yaş } \\
\text { arası } & 83 \\
\text { çocuk } & \\
\text { (Deney:40, } \\
\text { Kontrol:43) }\end{array}$ & $\begin{array}{l}\text { Beden } \\
\text { Güvenliği } \\
\text { Eğitim } \\
\text { Programı } \\
\text { Türkçe } \\
\text { Formu }\end{array}$ & $\begin{array}{|lr|}\text { Yedi } & \text { seans, } \\
\text { yedi } & \text { ardışık } \\
\text { gün, } & \text { her } \\
\text { seansta } & 20- \\
25 \text { dakika } & \\
\end{array}$ & \begin{tabular}{|l|} 
Beden \\
güvenliği \\
eğitimi kitabı, \\
senaryo
\end{tabular} & $\begin{array}{l}\text { Deney grubu çocuklarının uygun/uygun olmayan dokunmayı tanıma, söyleme, yapma, } \\
\text { anlatma ve bildirme becerileri kontrol grubu ile karşılaştırıldığında artış saptanmış, ön } \\
\text { test ve son test puan ortalamaları arasındaki fark istatistiksel olarak ileri düzeyde } \\
\text { anlamlı bulunmuştur ( } p<0.01) \text {. BGE Programı Türk çocuklarında, çocuğun cinsel } \\
\text { istismarını önleme ve kendini koruma becerilerini artırmada etkili bir program olduğu } \\
\text { sonucuna varmışlardır. }\end{array}$ \\
\hline $\begin{array}{l}\text { Çırık, Efe } \\
\text { ve } \\
\text { Velipaşaoğ } \\
\text { lu, 2019/ } \\
\text { Türkiye }\end{array}$ & $\begin{array}{lr}-6 & \text { yaş } \\
\text { arası } & 58 \\
\text { çocuk } & \text { ve } \\
64 & \\
\text { ebeveyn, } \\
\text { kontrol } \\
\text { grubu yok }\end{array}$ & $\begin{array}{l}\text { Child Sexual } \\
\text { Abuse } \\
\text { Training } \\
\text { Program }\end{array}$ & \begin{tabular}{|l|}
1 günlük ve \\
toplam \\
dakika
\end{tabular} & \begin{tabular}{|ll|}
\multicolumn{2}{|c|}{ Eğitici afişler, } \\
videolar ve \\
resimler, \\
Kiko ve El \\
kitabı
\end{tabular} & $\begin{array}{l}\text { Çalışmada ön test/son test tasarımı kullanılmıştır. Ebeveynlerinden çocuk cinsel } \\
\text { istismarı önleme eğitimi alan çocuklarda, cinsel istismardan şüphelenmeleri } \\
\text { durumunda ne yapmaları gerektiği ve özel bölgeleri ögrenme bilgilerinde gelişme } \\
\text { gösterdiği belirtilmiştir. Çalışmanın sonucunda ebeveynler cinsel istismarı çocuklara } \\
\text { doğru bir şekilde öğretirlerse, çocuklarda istismar riskini azaltılabileceği ifade edilmiştir }\end{array}$ \\
\hline
\end{tabular}




\section{Okul Temelli Cinsel İstismarı Önleme Programlarının İçeriği ve Uygulanması}

Okul temelli cinsel istismarı önleme programları kapsamında ele alınan ana konu başıkları aşağıdaki gibidir:

- Çocuklara bedenlerinin tanıtılması,

- Özel bölge kavramı ve bedeninin hangi bölümlerinin "özel bölge" olarak kabul edildiğini öğrenmesi,

- Özel bölgeleri için doğru isimleri (ör., penis, vajina, meme, popo) öğrenmeleri,

- Çocukların beden güvenliği hakkında bilgi sahibi olmaları ve uygun/iyi dokunuş ve uygun olmayan/kötü dokunuş arasındaki farkı öğrenme,

- Sır saklamama, uygun (iyi sır) ve uygun olmayan (kötü sırlar) sırlar arasındaki farkı öğrenme,

- Çocuklar beden güvenliği ile ilgili sınır ihlalinde bir şey yaşarlarsa; "Hayır" deme, ortamdan uzaklaşma veya güvendiği yetişkinlere anlatma gibi kendini koruma becerileri kazandırma,

- Çocukların destek sistemleri hakkında bilgi edinmeleri sağlama,

- Yabancılarla güvenli sınır oluşturması gerektiğini öğretilmesini sağlamaktır $[9,18,22,30,31]$.

Okul öncesi yaş grubu için özel olarak tasarlanmış bir program seçmek iyi bir yöntem olacaktır. Hem müfredat içeriği hem de sunum tarzı oldukça önemlidir [32]. Başarılı önleme programları incelendiğinde, özellikle eğitime aktif katılan öğrencileri içeren programlarda, öğrenciler daha fazla bilgi öğrenmiş ve becerilerde daha iyi gelişim göstermiştir. Aktif katıım pasif öğrenmeye kıyasla daha başarıı bulunmuştur. Ayrıca yapılan tekrarlarda becerileri tam anlamıyla kazanmalarına yardımcı olduğundan, çocukların kavramları her yıl yeniden tekrarlamaları da oldukça yararlıdır. Rol yapma ve sözlü tartışmanın her ikisinin kullanımı, öğrencilerin hiç katılmama durumundan daha yüksek etki göstermiştir. Programları okul öncesi çocuklara uygun hale getirmek için yapılabilecek değişiklikler arasında daha fazla aile katılımı, daha fazla dikkat/ilgi çekici etkinlikler, soyut kavramlara karşı daha fazla somut kavramlara odaklanma, daha fazla uygulama fırsatı ve daha fazla tekrar yer almalıdır. Başarılı önleme programlarında; bilgiyi tanıma ve uygulama fırsatları sağlamak için modelleme, tartışma, rol yapma, videolar, kukla gösterileri ve oyunlar gibi ilgi çekici aktivitelerin daha fazla kullanması gerektiği belirtilmiştir [19,32-34].

\section{Ebeveynlerin Rolü}

Özellikle okul öncesi çağındaki çocukların ebeveynleri, çocuklarının koruyucusu ve eğitimcisi olarak çok önemli bir rol oynarlar. Literatürde okul temelli cinsel istismarını önleme programlarına ebeveyn katıımının oldukça önemli olduğu ve bu programların başarısının artmasıyla ilişkili olduğu bildirilmiştir [1,9,33,35-37]. Çünkü istismar hakkında ebeveynlerin çocuklarıyla daha fazla iletişime geçmesi ve kavramların daha fazla tekrar edilmesiyle ilgili olduğu düşünülmektedir. Ayrıca ebeveynlerin çocuk cinsel istismarının tipik belirti ve semptomlarını öğrenmesi, çocuk cinsel istismar vakalarının hızla önlenmesine katkıda bulunması açısından oldukça önemlidir. Bu önleme programları aracılığıyla, ebeveynler olası istismarın ortaya çıkması durumunda nasıl başa çıkacaklarını, çocuklarına en uygun şekilde nasıl rehberlik edebileceklerini ve aynı zamanda çocuklarına güvenli bir altyapıyı nasıl verebileceklerini öğrenmektedirler $[9,13,38,39]$.

\section{Öğretmenin Sorumlulukları}

Çocukların ailelerinden sonra en fazla vakit geçirdikleri yer okullarıdır. Çocukların, gün içinde ebeveynlerinden bile daha uzun süre öğretmenleriyle zaman geçirdiği düşünüldüğünde ve çocuk gelişiminde uzman olmaları nedeniyle istismarı önleme çalışmalarında öğretmenlerde yer almalıdır $[22,40,41]$. Okul öncesi dönemdeki çocuklara yönelik hazırlanmış olan cinsel istismarı önleme programları okul öncesi öğretmenleri tarafından faydalı programlar olarak kabul edilmektedir [42]. Çocukların öğretmenleriyle daha fazla iletişime geçmesi, sorunlarını onlara anlatabiliyor olmaları, öğretmenlerin çocuklardaki davranış değişikliklerini fark edebilmeleri ve bildirim yapma zorunluluklarııın olması gibi nedenler, çocuk istismarını belirlemede ve önlemede öğretmenlerin rollerinin ne kadar önemli olduğunu göstermektedir. Ayrıca, öğretmenlerin çocuklara ve ailelerine istismarı önleme konusunda eğitim verme imkânlarının bulunması çocukları korumada önemli bir firsattır [40,41].

Çocuk cinsel istismarının önlenmesine odaklanan profesyonellerde eğitim eksikliğinin olması önemli bir sorundur. Yapılan çalışmalarda, okul öncesi öğretmenlerinin çocuk istismarı ve ihmali konusunda 
duyarlıık gösterdikleri, birtakım bilgilere sahip oldukları ancak bu bilgilerin yetersiz olduğu saptanmıştır $[40,43,44]$. Bu nedenle okullarda verilecek olan önleme programlarında, öğretmenler ve okul personelinin cinsel istismar konusunda eğitilmeleri ve özellikle öğretmenlerin ihmal ve istismar durumlarında nasıl bir yol izleyeceklerine ilişkin eğitimler verilmesi önerilmiştir $[32,33,44]$.

\section{Cinsel İstismarı Önlemede Hemşirenin Rol ve Sorumlulukları}

Amerikan Hemşireler Birliği tarafından 1976 yılında Hemşirelik kodları içerisinde yer alan hasta haklarının savunuculuğu rolü kapsamında, çocukları inmal ve istismardan korumayı da içermektedir. Hemşireler savunucuk rolü kapsamında çocuk haklarının ihlal edildiği durumlarda çocuğun haklarını savunma, ihmalden ve istismardan korumakla sorumludur [45]. DSÖ çocuk inmali ve istismarının önlenmesinde hemşirelerin önemli bir yeri olduğunu ifade etmiştir. Bu kapsamda hemşirelerin ev ziyaretleri sırasında; ebeveynlere çocuk yetiştirme becerilerinin geliştirilmesi, çocuk bakımının öğretilmesi, çocuk gelişimi (çocuğun fiziksel, duygusal ve cinsel gelişimi) ile ilgili bilgilerinin artırılması, çocuk yönetiminde olumlu stratejilerin geliştirilmesi, çocuk hakları, gerekli okul öncesi eğitim alması gibi konularda eğitim vermeleri gerektiği belirtilmiştir [45-47]. Ayrıca aile olası bir cinsel istismar durumu ile karşılaştığında başvurulacak (cumhuriyet savcılığı vb) kurum ve kuruluşlar hakkında bilgilendirilmelidir [47].

Hemşireler çocuk inmal ve istismarı konusunda çocuğa ve aileye yönelik risk faktörlerinin farkında olarak erken tanıda etkin rol almaktadırlar [48]. Sağlık ekibi içinde hemşire, gerek koruyucu, gerekse tedavi ve rehabilite edici aşamalarda istismar edilen çocuk ve ailesi ile ilk karşılaşan anahtar konumdaki sağlık ekibi üyesidir. Çocuk inmal ve istismarında hemşireler hem koruyucu, hem de tedavi ve rehabilite edici hizmetlerde üzerlerine düşen sorumlulukları yerine getirmelidirler [47]. Çocuk istismarı ve inmalinin önlenmesinde birincil hemşirelik girişimleri, toplumu ve meslek üyelerini inmal ve istismara karşı farkındalıklarını artırmaktır. Birincil düzey çalışmalar risk altındaki çocukların istismara maruz kalma olasılığına karşı çocuğun bilgi ve beceri açısından güçlendirilmesine yöneliktir. İkincil hemşirelik girişimleri, inmal ve istismarı erken tanımayı, istismar sonrası çocuk ve aileye yaklaşımı, çocuğun ve kardeşlerinin korunmasını içerir. Üçüncül girişimler ise istismarın çocuk üzerindeki etkilerini en aza indirmeyi kapsar [49]. En önemlisi ise hemşireler cinsel istismara uğramış bir çocukla karşılaştığında ya da şüphelendiği bir durumda bunu bildirmekle yükümlüdür [47].

\section{Programlara Yönelik Endişeler, Eleştiriler, Olumsuz Sonuçlar ve Kısıtlılıkları}

Önleme programlarında, bir çocuğun ailesi tarafından cinsel istismar olasılığı genellikle yer almaz $[9,50]$. Çoğu çocuk cinsel istismarı vakaları çocuğun bildiği kişiler tarafından olmasına rağmen; en yakın aile çevresinde işlenen bir eylem, önleme programlarında ele alınan ciddi bir zorluktur $[39,50]$. Ayrıca engelli çocuklarda, savunmasız olmaları nedeniyle istismar oranları daha fazladır. Ancak, önleme stratejileri şimdiye kadar engelli çocuklara odaklanmamış ve tam olarak bu gruba uyarlanmış programlar bulunmamaktadır [17].

Literatürde okul temelli programların etkinliği kanıtlanmasına rağmen, bu programların çocuğa çok fazla sorumluluk yüklediğine dair bazı eleştiriler de yer almıştır [30,35,39,51]. Çocukların bu konuya maruz kalması, çocuklarda kaygı artması veya yetişkinlerle olan ilişkilerinde güvenin azalması gibi olumsuz tepkilere de yol açabilir [39,52]. Ayrıca literatürde bilgi kazanımının günlük hayatta gerçek bir istismarla karşılaşma olasılığında kendini koruma davranışı geliştirip geliştirmediği de tartışılmaktadır $[9,31,35,52,53]$. Bunlara ek olarak, önleme programlarının tasarım ve içeriği, süresi, eğitimsel çıktıları ve değerlendirme stratejileri ile ilgili bir uyumsuzluğa işaret ederek programın kendisiyle ilgili olumsuz yorumlar olmuş $[52,54]$ ve araştırmalarda programın maliyetleri genellikle hesaplanmadığına dair bazı eleştiriler de bulunmaktadır $[52,55]$.

\section{Sonuç}

Okul öncesi dönem çocuğun, bedensel, psikomotor, sosyal-duygusal, bilişsel ve dil gelişiminin büyük ölçüde tamamlandığı bir dönemdir. Bu dönemdeki çocuk anatomik ve cinsiyet farklıııkları konusunda meraklıdır ve keşfetmeye çalışır. Öğrenme hızının çok yüksek olduğu okul öncesi dönemde alınan eğitim, çocuğun hayatını doğrudan etkilemektedir. Okul öncesi döneme ait bu gelişim özellikleri nedeniyle literatürde cinsel istismarı önleme programlarının 3-6 yaşta verilmesi gerektiği vurgulanmaktadır.

Çocuk istismarında temel hedef çocuk cinsel istismarının önlenmesidir. Çocuğun sağlıklı bedensel, ruhsal, duygusal, cinsel gelişimi ve cinsel istismardan korunması için "Okul Temelli Cinsel İstismarı Önleme Programları" oldukça önemlidir. Bu eğitim programında çocuklara "bedenim bana ait bilinci”nin 
kazandırılması temel hedef olmalıdır. Çocuklara yönelik bu programların temel amacı; çocukların olası istismar durumlarını tanımalarını, uygun bir yolla tepki göstermelerini ve böyle bir durumda güvendikleri bir yetişkine olayı anlatmalarını hedeflemelidir. Ancak göz ardı edilmemesi gereken önemli bir nokta çocuğa sağlanacak olan eğitimin amacı farkındalık kazanmasına yönelik olarak bilgi ve beceri kazandırmak olmalıdır. Çocukta kaygı, korku, yanlış ve olumsuz bir algı oluşturacak şekilde olmamalıdır.

Bu programların, çocukların cinsel istismarı önleme konusundaki bilgilerini artırmada, beden güvenliği kurallarını ve becerilerini öğretmede etkili olduğu çok sayıda çalışmada kanıtlanmıştır. Bu doğrultuda gelişmiş ülkelerde önleme çalışmaları kapsamında okul temelli cinsel istismarı önleme programları uygulanmaktadır. Başta çocuklar olmak üzere geliştirilen bu tür programlara ebeveynlerin, öğretmenlerin, okul personelinin, çocuk ve okul sağlığı hemşirelerinin de dâhil edilmesinin oldukça gerekli olduğu düşünülmektedir. Ancak çocuk istismarının önlenmesinde bu programlarının etkinliği kanıtlanmasına rağmen Ülkemizde kullanılmadığı ve bu alanda yapılan tez ve araştırmaların yetersiz olduğu, çocuk ve okul sağlığı hemşirelerinin konuya ilişkin yapacakları araştırmaların sayısının ve niteliğinin artmasının önemine dikkat çekilmiştir.

\section{Kaynakça}

[1] Lynas J, Hawkins R. Fidelity in school-based child sexual abuse prevention programs: A systematic review. Child Abuse Neglect. 2017;72:10-21.

[2]Child Maltreatment World Health Organization 2017 [Available from: https://www.who.int/violence_injury_prevention/violence/child/Child_maltreatment_infographic_EN.pdf.

[3]Türkiye'deki Risk Altındaki Çocuklar Raporu 2019 [Available from: https://www.tocev.org.tr/Uploads/Documents/TOCEV\%20Rapor\%5B2\%5D.pdf?fp=2608929755.

[4]Güven ŞT, Dalgiç Aİ, Erkol Z. Emotional and psychosocial problems encountered by children who have been sexually abused. Journal of Psychosocial Nursing and Mental Health Services. 2017;56(2):37-43.

[5]Hunt R, Walsh K. Parents' views about child sexual abuse prevention education: A systematic review. Aust J Early Child. 2011;36(2):63-76.

[6]Sarı HY, Ardahan E, Öztornacı BÖ. Çocuk ihmal ve istismarına ilişkin son 10 yılda yapılan sistematik derlemeler. TAF Preventive Medicine Bulletin. 2016;15(6):501-11.

[7]Levine JA, Dandamudi K. Prevention of child sexual abuse by targeting pre-offenders before first offense. Journal of child sexual abuse. 2016;25(7):719-37.

[8]Kenny MC, Wurtele SK. Preventing childhood sexual abuse: An ecological approach. Journal of Child Sexual Abuse. 2012;21(4):361-7.

[9]Wurtele SK. Preventing sexual abuse of children in the twenty-first century: Preparing for challenges and opportunities. Journal of Child Sexual Abuse. 2009;18(1):1-18.

[10]Özdemir AA, Ramazan O. Oyuncağa çocuk, anne ve öğretmen bakış açısı. Eğitim Bilimleri Araştırmaları Dergisi. 2012;2(1):1-16.

[11]Wurtele SK, Kenny MC. Normative sexuality development in childhood: Implications for developmental guidance and prevention of childhood sexual abuse. Counseling and Human Development. 2011;43(9):1-24.

[12]Al-Rasheed M. Child Sexual Abuse Prevention Programs for Kindergartners: A Survey of Public Actions, Attitudes, and Beliefs in Kuwait. Child Adolesc Soc Wo. 2017;34(4):361-8.

[13]Citak Tunc G, Gorak G, Ozyazicioglu N, Ak B, Isil O, Vural P. Preventing child sexual abuse: Body safety training for young children in Turkey. Journal of Child Sexual Abuse. 2018;27(4):347-64.

[14]Wurtele SK. Behavioral approaches to educating young children and their parents about child sexual abuse prevention. The Journal of Behavior Analysis of Offender and Victim Treatment and Prevention. 2008;1(1):52.

[15]Zhang WJ, Chen JQ, Feng YN, Li JY, Liu CF, Zhao XX. Evaluation of a sexual abuse prevention education for Chinese preschoolers. Res Social Work Prac. 2014;24(4):428-36.

[16]Kenny MC. Child sexual abuse education with ethnically diverse families: A preliminary analysis. Child Youth Serv Rev. 2010;32(7):981-9. 
[17]Kenny MC, Wurtele SK. Toward prevention of childhood sexual abuse: Preschoolers' knowledge of genital body parts. American Journal of Sexuality Education. 2013;3:345-54.

[18]Rudolph J, Zimmer-Gembeck MJ, Shanley DC, Hawkins R. Child sexual abuse prevention opportunities: Parenting, programs, and the reduction of risk. Child maltreatment. 2018;23(1):96-106.

[19]Brassard MR, Fiorvanti CM. School-based child abuse prevention programs. Psychology in the Schools. $2015 ; 52(1): 40-60$.

[20]Plummer CA. The history of child sexual abuse prevention: A practitioner's perspective. Journal of Child Sexual Abuse. 1999;7(4):77-95.

[21]Tutty L, Bradshaw C, Thurston W, Barlow A, Marshall P, Tunstall L, et al. School based violence prevention programs: Preventing violence against children and youth 2005 [Available from: https://www.academia.edu/1597984/School_based_violence_prevention_programs_Preventing_violence_against _children_and_Youth_Revised_Ed_.

[22]Zeuthen K, Hagelskjær M. Prevention of child sexual abuse: Analysis and discussion of the field. Journal of Child Sexual Abuse. 2013;22(6):742-60.

[23]Wurtele SK, Saslawsky DA, Miller CL, Marrs SR, Britcher JC. Teaching personal safety skills for potential prevention of sexual abuse: A comparison of treatments. Journal of Consulting and Clinical Psychology. 1986;54(5):688.

[24]Brown DM. Evaluation of safer, smarter kids: child sexual abuse prevention curriculum for kindergartners. Child and adolescent social work journal. 2017;34(3):213-22.

[25]Dunn M. The learning of sexual abuse prevention concepts and the reliability of the CKAQ-RIII in the South African Context. Social Work/Maatskaplike Werk. 2011;47(2).

[26]Weatherley R, Hajar AS, Noralina O, John M, Preusser N, Yong M. Evaluation of a school-based sexual abuse prevention curriculum in Malaysia. Children and Youth Services Review. 2012;34(1):119-25.

[27]Kim S-J, Kang K-A. Effects of the child sexual abuse prevention education (C-SAPE) program on south korean fifth-grade students' competence in terms of knowledge and self-protective behaviors. The Journal of School Nursing. 2017;33(2):123-32.

[28]Chen Y, Fortson BL, Tseng K-W. Pilot evaluation of a sexual abuse prevention program for Taiwanese children. Journal of Child Sexual Abuse. 2012;21(6):621-45.

[29]Bustamante G, Andrade MS, Mikesell C, Cullen C, Endara P, Burneo V, et al. "I have the right to feel safe": Evaluation of a school-based child sexual abuse prevention program in Ecuador. Child abuse \& neglect. 2019;91:31-40.

[30]Hawkins R. Protecting children from sexual abuse. InPsych. 2013;35:16-7.

[31]Walsh K, Zwi K, Woolfenden S, Shlonsky A. School-based education programs for the prevention of child sexual abuse: A Cochrane systematic review and meta-analysis. Research on social work practice. 2018;28(1):33-55.

[32]Kenny MC, Wurtele SK. Preschoolers' knowledge of genital terminology: A comparison of English and Spanish speakers. American Journal of Sexuality Education. 2008;3(4):345-54.

[33]Kenny MC, Capri V, Ryan EE, Runyon MK. Child sexual abuse: from prevention to self-protection. Child Abuse Review: Journal of the British Association for the Study and Prevention of Child Abuse and Neglect. $2008 ; 17(1): 36-54$.

[34]Zwi KJ, Woolfenden SR, Wheeler DM, O'Brien T A, Tait P, Williams KW. School-based education programmes for the prevention of child sexual abuse. Cochrane Database Syst Rev. 2007(3):Cd004380.

[35]Kenny M, Wurtele SK, Alonso L. Evaluation of a personal safety program with Latino preschoolers. Journal of Child Sexual Abuse. 2012;21(4):368-85.

[36]Xie QW, Qiao DP, Wang XL. Parent-involved prevention of child sexual abuse: A qualitative exploration of parents' perceptions and practices in Beijing. Journal of Child and Family Studies. 2016;25(3):999-1010. 
[37]Zhang W, Chen J, Feng Y, Li J, Zhao X, Luo X. Young children's knowledge and skills related to sexual abuse prevention: A pilot study in Beijing, China. Child Abuse Negl. 2013;37(9):623-30.

[38]Wurtele SK, Kenny MC. Partnering with parents to prevent childhood sexual abuse. Child Abuse Review: Journal of the British Association for the Study and Prevention of Child Abuse and Neglect. 2010;19(2):130-52.

[39]Finkelhor D. The prevention of childhood sexual abuse. The future of children. 2009:169-94.

[40]Erdoğan Y, Aslan D. Okul öncesi öğretmenlerinin çocuk istismarı ve inmaline yönelik algıları. Mersin Üniversitesi Eğitim Fakültesi Dergisi. 2020;16(1):104-32.

[41]Koçtürk N. Çocuk inmalini ve istismarını önlemede okul çalışanlarının sorumlulukları. Muğla Sıtkı Koçman Üniversitesi Eğitim Fakültesi Dergisi. 2018;5(1):38-47.

[42]Pitts C. Child sexual abuse prevention programs for pre-schoolers: A synthesis of current evidence: Royal Commission into Institutional Responses to Child Sexual Abuse Sydney; 2015.

[43]Aksel EŞ, Irmak TY. Çocuk cinsel istismarı konusunda öğretmenlerin bilgi ve deneyimleri. Ege Eğitim Dergisi. 2015;16(2):373-91.

[44]Kardeş S, Karaman NG. Okul Öncesi Eğitim Öğretmenlerinin Çocuğun Cinsel Eğitimine İlişkin Görüşleri. Abant İzzet Baysal Üniversitesi Eğitim Fakültesi Dergisi. 2018;18(3):1554-70.

[45]Bakır E, Kapucu S. Çocuk inmali ve istismarının Türkiye'de yapılan araştırmalara yansıması: Bir literatür incelemesi. Hacettepe Üniversitesi Hemşirelik Fakültesi Dergisi. 2017;4(2):13-24.

[46]Polat O. Tüm boyutlarıyla çocuk İstismarı: Tanımlar. Ankara: Seçkin Yayıncılık; 2007.

[47]Kaya H, Çoban B, Killiklioğlu E, Özden N, Özgen G. Çocukta cinsel istismar ve hemşirenin rolü. Florence Nightingale Hemşirelik Dergisi. 2005;13(55):57-62.

[48]Yıımaz B, Çalışkan D. Bir hastanede çalışan hemşirelerin çocuk inmal ve istismarına yönelik bilgi ve yaklaşımlarının incelenmesi. Sağlık Akademisi Kastamonu. 2015;4(2):1-15.

[49]Koyun A, Taşkın L, Terzioğlu F. Yaşam dönemlerine göre kadın sağlığı ve ruhsal işlevler: Hemşirelik yaklaşımlarının değerlendirilmesi. Psikiyatride Güncel Yaklaşımlar. 2011;3(1):67-99.

[50]Murray LK, Nguyen A, Cohen JA. Child sexual abuse. Child and Adolescent Psychiatric Clinics. 2014;23(2):321-37.

[51]Smallbone S, Marshall WL, Wortley R. Preventing child sexual abuse: Evidence, policy and practice: Routledge; 2013.

[52]Fryda CM, Hulme PA. School-based childhood sexual abuse prevention programs: An integrative review. The Journal of School Nursing. 2015;31(3):167-82.

[53]Kenny MC. Child sexual abuse prevention: Psychoeducational groups for preschoolers and their parents. The Journal for Specialists in Group Work. 2009;34(1):24-42.

[54]Davis MK, Gidycz CA. Child sexual abuse prevention programs: A meta-analysis. Journal of clinical child psychology. 2000;29(2):257-65.

[55]Manheim M, Felicetti R, Moloney G. Child sexual abuse victimization prevention programs in preschool and kindergarten: implications for practice. Journal of child sexual abuse. 2019;28(6):745-57. 
